Boise State University

ScholarWorks

Biology Faculty Publications and Presentations

Department of Biological Sciences

$7-1-2018$

Modification of Diet and Foraging Range by

Harvester Ants in Response to Altered Seed

Availability

Ian C. Robertson

Boise State University

Matthew S. Schmasow

Boise State University

This is an author-produced, peer-reviewed version of this article. The final, definitive version of this document can be found online at Journal of Insect

Behavior, published by Springer. Copyright restrictions may apply. The final publication is available at doi: 10.1007/s10905-018-9685-x 
This is an author-produced, peer-reviewed version of this article. The final, definitive version of this document can be found online at Journal of Insect Behavior, published by Springer. Copyright restrictions may apply. doi: 10.1007/s10905-018-9685-x

\title{
Modification of Diet and Foraging Range by Harvester Ants in Response to Altered Seed Availability
}

\author{
Ian C. Robertson* \\ Department of Biological Sciences \\ Boise State University \\ iroberts@boisestate.edu
}

\author{
Matthew S. Schmasow \\ Department of Biological Sciences \\ Boise State University
}

\section{Acknowledgments}

This study was conducted with funding from the Idaho Army National Guard, United States Fish \& Wildlife Service, and Boise State University. We thank Samantha Gardner for assistance with fieldwork, and Julie Heath, Jennifer Forbey and two anonymous reviewers for helpful comments on earlier drafts of the manuscript.

\begin{abstract}
Food collection is a critical component of an individual's life, and for eusocial insects, the colony that individual foragers support and maintain. Changes to the distribution and composition of food types in the environment are expected influence diet selection if the economics of foraging are altered. For seed-harvesting ants, the abundance and composition of seed types available on the ground typically shows a high degree of spatial and temporal variability, and not all types of seed are equally valued by foragers. We evaluated the response of Owyhee harvester ants (Pogonomyrmex salinus) to reductions in the availability of Sandberg bluegrass (Poa secunda) seeds, a preferred food type, while leaving the availability of cheatgrass (Bromus tectorum) seeds, a less favored food type, unmanipulated. At control colonies $(\mathrm{N}=8)$, cheatgrass seeds comprised $3.9 \pm 1.6 \%$ of total seed intake, while Sandberg bluegrass seeds accounted for the remainder of the diet. At colonies where bluegrass was trimmed to prevent new seeds from dropping within $12 \mathrm{~m}$ of the nest $(\mathrm{N}=8)$, cheatgrass seed intake increased significantly to $8.2 \pm 1.4 \%$ of the diet. Despite the uptick in collection of cheatgrass seeds, bluegrass seed collection remained high and very similar between treatment and control colonies. Treatment colonies were significantly more likely than control colonies to have at least one trunk trail that extended beyond the $12 \mathrm{~m}$ foraging range of the colony, and ants returning along these trails carried bluegrass seeds but not cheatgrass seeds. These results suggest that when preferred seeds dropped in abundance near nests, the economics of foraging by harvester ants favored a small increase in acceptance of less preferred seeds as well as more distant forays to locate and collect preferred seeds.
\end{abstract}

Keywords: seed predation, foraging, harvester ant, Pogonomyrmex salinus, Poa secunda, Bromus tectorum

\section{Introduction}

Food collection is a critical component of an individual animal's life, and for eusocial insects, the colony that individual foragers support and maintain. Natural selection should favor individuals that maximize energy intake per unit time, subject to limitations caused by imperfect knowledge of food availability in the environment (Stephens and Krebs 1986; Stephens et al. 2007). Changes to the distribution and composition of food types in the environment are expected to influence diet selection if the economics of foraging are altered (MacArthur and Pianka 1966; Davidson 1978; Crist and MacMahon 1992; Kerley et al. 2010). Here we examine whether Owyhee harvester ants, Pogonomyrmex salinus (Hymenoptera: Formicidae), alter diet selection and foraging patterns in response to changes in the availability of preferred seeds on the soil surface near their nests.

Harvester ants in the genus Pogonomyrmex are large-scale collectors and consumers of plant seeds and propagules in many arid and semiarid ecosystems of the Americas (Johnson 2000). Their nest mounds often dot the landscape, and typically range in density from 10-80 colonies/ha (MacMahon et al. 2000). In temperate climates, harvester ants 
This is an author-produced, peer-reviewed version of this article. The final, definitive version of this document can be found online at Journal of Insect Behavior, published by Springer. Copyright restrictions may apply. doi: 10.1007/s10905-018-9685-x

forage diurnally from spring to autumn whenever surface temperatures are sufficiently warm, gathering large numbers of seeds from the soil surface, as well as insects, soil particles, feces, sticks, and leafy vegetation (Taber 1998; Belchior et al. 2012). In most species, individual foragers travel to and from their nest along habitual foraging trails that radiate away from the nest, gradually dissipating into resource patches where foragers search for food (Gordon 1991, 1995; MacMahon et al. 2000). In some cases, these trails exist as narrow visible clearings of vegetation, or "trunk trails" (Hölldobler 1976). The formation and use of trunk trails by foragers is influenced in part by the quality and distribution of food patches, as well as by competition with adjacent colonies (MacMahon et al. 2000; Howell and Robertson 2015).

Although harvester ants collect and consume seeds from a wide range of plant species in the environment, they exhibit marked preferences for certain kinds of seed, with grasses, mustards, and other small-seeded species often figuring prominently in diet (Crist and MacMahon 1992, Detrain and Pasteels 2000, Pirk et al. 2009, Pirk and Lopez de Casenave 2011; Schmasow and Robertson 2016). Seed selectivity is influenced by the relative seasonal abundance of seeds (Whitford 1978; Briese and Macauley 1981; Mehlhop and Scott 1983; Crist and MacMahon 1992; Pirk et al. 2009; Pol et al. 2011), size and morphology of seeds (Peters et al. 2003, Pirk and Lopez de Casenave 2010, 2011; Hickey et al. 2016), nutritional quality of seeds (Kelrick et al. 1986; Crist and MacMahon 1992; Kay 2004), and competition with other species of seed harvesting ants (Mehlhop and Scott 1983). In general, harvester ants adopt a time minimization strategy rather than a net energy gain per item returned strategy (Weier and Feener 1995; Morehead and Feener 1998; Heredia and Detrain 2005; Pirk and Lopez de Casenave 2010). Preference is given to nutritious seeds that can be quickly collected and transported back to the nest (Kelrick et al. 1986; Crist and MacMahon 1992; Schmasow and Robertson 2016).

Studies of seed selection by harvester ants often rely on cafeteria-style or pairwise choice experiments using seeds placed on trays (i.e., artificial food patches) near trunk trails to evaluate and establish hierarchies of preference for naturally occurring seeds (Kelrick et al. 1986; Gross et al. 1991; Crist and MacMahon 1992; Pirk and Lopez de Casenave 2011; Ostoja et al. 2013). Some food-patch studies rely on the use of commercial seeds with known morphological and nutritional attributes (e.g., millet, sesame, oats) in order to select for desired seed traits in choice experiments (Davidson 1978; Holder Bailey and Polis 1987; Fewell and Harrison 1991; Heredia and Detrain 2005). Although artificial food-patch studies, including those using commercial seeds, have helped to identify factors that influence the foraging decisions of harvester ants, the importance of natural resource availability within the foraging range of individual colonies is often overlooked. Because the identity, abundance, and spatial distribution of naturally occurring seeds around ant colonies can influence the selectivity of foragers (Detrain et al. 2000; Guarino et al. 2005; Pirk et al. 2009), efforts to characterize and understand selectivity by ants should include foraging scenarios that reflect conditions ants experience naturally within their habitat (Crist and MacMahon 1992).

In southwestern Idaho, Owyhee harvester ants foraging in open grassland prefer the seeds of Sandberg bluegrass (Poa secunda) and tall tumblemustard (Sisymbrium altissimum) to those of cheatgrass (Bromus tectorum), as indicated by the consistent overrepresentation of $P$. secunda and $S$. altissimum seeds in the diet, and the underrepresentation of $B$. tectorum seeds despite their widespread abundance on the soil surface (Schmasow and Robertson 2016). Similar findings have been reported for the western harvester ant, Pogonomyrmex occidentalis (Kelrick et al. 1986; Crist and MacMahon 1992; Ostoja et al. 2013). The relatively long length of B. tectorum seeds, along with their persistent bristled awn, makes them difficult for ants to transport. In contrast, the seeds of $P$. secunda and $S$. altissimum are small enough to be transported to nests with relative ease (Schmasow and Robertson 2016). Although individual $B$. tectorum seeds contain about 12 times the caloric content of $P$. secunda and $S$. altissimum seeds, on a gram for gram basis $S$. altissimum seeds and $P$. secunda seeds provide more energy than $B$. tectorum seeds, and they contain significantly higher percent crude protein than B. tectorum seeds (Schmasow and Robertson 2016).

In the present study, we experimentally reduced the abundance of Sandberg bluegrass seeds located within a $12 \mathrm{~m}$ radius of Owyhee harvester ant colonies to test whether ants would (1) increase their uptake of cheatgrass seeds in response to lower availability of bluegrass seeds on the soil surface near their nests, (2) search greater distances for bluegrass seeds when nearby sources were partially depleted, or (3) both. We chose a $12 \mathrm{~m}$ radius because although Pogonomyrmex ants travel up to $25 \mathrm{~m}$ in search of food, most foraging takes place within 10-12 m of nests (MacMahon et al. 2000; personal observations). We relied on the natural spatial distribution of plants around colonies to create a more realistic foraging environment than can be achieved using artificial food patches placed near trunk trails. 
This is an author-produced, peer-reviewed version of this article. The final, definitive version of this document can be found online at Journal of Insect Behavior, published by Springer. Copyright restrictions may apply. doi: 10.1007/s10905-018-9685-x

\section{Methods}

\section{Study Site}

We conducted the study from mid-May through July 2011 at a 10-ha site located within a population of Owyhee harvester ants ( $\sim 25.5$ colonies/ha) near Melba, Idaho (43⒉ $\left.3^{\prime} 14.49^{\prime \prime} \mathrm{N} / 116^{\circ} 28^{\prime} 44.59^{\prime \prime} \mathrm{W}\right)$. Following a wildfire in the late 1990's, the plant community at this site shifted from sagebrush-steppe to open grassland dominated by Sandberg bluegrass (Poa secunda), cheatgrass (Bromus tectorum), and tall tumblemustard (Sisymbrium altissimum). Of those species, only $P$. secunda is native to the area. However, both B. tectorum and S. altissimum have a long postfire invasion history in southern Idaho (Piemeisel 1951), and both are a regular part of the landscape in which Owyhee harvester ants forage. Sparse patches of Wyoming big sagebrush (Artemisia tridentata ssp. wyomingensis), gray rabbitbrush (Ericameria nauseosa), brome fescue (Vulpia bromoides), bluebunch wheatgrass (Agropyron spicatum), crested wheatgrass (Agropyron desertorum), and slickspot peppergrass (Lepidium papilliferum) are scattered throughout the site but did not factor prominently around the ant colonies included in our study.

\section{$\underline{\text { Ant Colonies and Seed Manipulations }}$}

We selected 16 harvester ant colonies that were at least $40 \mathrm{~m}$ apart from one another to reduce competition effects among colonies and ensure statistical independence of samples. Any S. altissimum growing within a $12 \mathrm{~m}$ radius of colonies was removed weekly using a gasoline-powered rotary weed trimmer to limit the foraging options available to ants to just two species - P. secunda and B. tectorum. Although S. altissimum was abundant at the site in 2011, in some years it is rare (unpublished data). Therefore, its removal did not create an unusual foraging scenario for ants. Following removal of $S$. altissimum, mean $( \pm \mathrm{SE})$ overhead coverage within the $12 \mathrm{~m}$ radius of ant colonies was $14.6 \pm 3.1 \%$ P. secunda, $39.7 \pm 6.5 \%$ B. tectorum, $1.9 \pm 0.9 \%$ other plant species (primarily Artemisia tridentata and the non-flowering remnants of trimmed S. altissimum), and $43.8 \pm 6.2 \%$ bare ground, including biological soil crust.

We randomly assigned eight of the 16 ant colonies to the control and the remainder to the treatment. We did not alter the vegetation around control colonies, apart from the weekly removal of S. altissimum as described above. Around treatment colonies, we deployed the weed trimmer in late May to remove the fruiting structures of $P$. secunda located within a $12 \mathrm{~m}$ radius of each colony. Trimming occurred before $P$. secunda had matured sufficiently to produce seeds and was repeated weekly to ensure these plants did not contribute to the surface seed pool. The removal of fruiting structures on $P$. secunda, while leaving B. tectorum plants intact, was facilitated by the uniformly taller height of $P$. secunda fruiting structures relative to those of $B$. tectorum. Loose vegetative debris caused by trimming was lightly raked and removed from the experimental areas as much as possible.

\section{Seed Availability}

One day prior to the initial trimming of $P$. secunda, we sampled for seeds around all treatment and control ant colonies to determine how much $P$. secunda and B. tectorum seed from previous years was present on the soil surface. We took $10,5.3 \mathrm{~cm}$ diameter soil cores at random locations within the $12 \mathrm{~m}$ foraging radius of each colony. In order to sample only those seeds available to foragers, we brushed loose surface debris, including seeds, from the upper 0.5 $\mathrm{cm}$ of each core sample and placed the debris into a zip-lock bag. We pooled the 10 sub-samples into one sample per colony. In the laboratory, we sifted the samples through a series of increasingly finer sieves $(1.4 \mathrm{~mm}, 850 \mu \mathrm{m}, 710$ $\mu \mathrm{m}, 500 \mu \mathrm{m}$, and $250 \mu \mathrm{m}$ diameter mesh, Hogentogler \& Co., Inc.), from which seeds were collected, identified and counted by hand under 10x magnification. This sampling procedure was repeated six and eight weeks after the initial sampling. The six-week pause before our first resampling effort allowed $P$. secunda at the control colonies sufficient time to mature and drop their seeds.

\section{Seed Intake and Trunk Trail Formation}

We conducted weekly observations throughout July at each ant colony to determine whether experimental reduction of Sandberg bluegrass seed abundance altered ant foraging behavior. Specifically, we determined whether the number and species identity of seeds returned to nests by harvester ants differed between treatment and control, and whether the reduction in bluegrass seeds around treatment colonies led to an increase in the formation of trunk trails that extended beyond $12 \mathrm{~m}$ of nests. Observations were conducted between 0900 and 1200 , the time during which ants were most active in foraging. We visited the colonies in random order each week to avoid any bias in foraging activity 
This is an author-produced, peer-reviewed version of this article. The final, definitive version of this document can be found online at Journal of Insect Behavior, published by Springer. Copyright restrictions may apply. doi: 10.1007/s10905-018-9685-x

associated with time of day. Observations at each colony lasted five minutes, during which time we visually identified and recorded the type of seed carried by each ant as it returned to its nest. Prior to each observation period, we noted the presence or absence of active trunk trails that extended beyond $12 \mathrm{~m}$ of the nest. Trunk trails were deemed active if we observed harvester ants moving along the trail away from their nest, or along the trail back to their nest while carrying seeds.

\section{$\underline{\text { Statistical Analyses }}$}

We used two-tailed t-tests to confirm that colonies assigned to treatment and control at the start of the experiment did not differ in the number of $\mathrm{P}$. secunda or B. tectorum seeds on the soil surface within $12 \mathrm{~m}$ of each nest. Treatment effects on P. secunda and B. tectorum seed abundance on the soil surface in July were analyzed using a $2 \times 2$ (treatment/control; second/fourth week of July) mixed factorial repeated measures ANOVA with repeated measures on the second factor (week). We used a one-tailed test in this instance because the trimming of P. secunda at the start of the experiment was expected to have only a negative effect on P. secunda seed numbers. Weekly differences in numbers of $\mathrm{P}$. secunda and $\mathrm{B}$. tectorum seeds collected and returned to nests by foraging ants were analyzed using a two-tailed 2x4 (treatment/control; sampling weeks 1 through 4) mixed factorial repeated measures ANOVA with repeated measures on the second factor (week). We log transformed the data where appropriate to improve normality. We used a Cochran-Mantel-Haenszel test (Cochran 1954; Mantel and Haenszel 1959) to account for repeated measures when testing for an effect of treatment on the number of colonies with and without trunk trails that extended beyond $12 \mathrm{~m}$ of the colony. All analyses were conducted using SAS 9.3.

\section{Results}

\section{Seed Availability}

The surface soil core samples we collected contained only B. tectorum and P. secunda seeds. The absence of $S$. altissimum seeds in these samples, as well as in foraging observations, confirmed that the frequent removal of $S$. altissimum from the vicinity of ant colonies effectively eliminated their seeds from the surface seed pool. In a concurrent experiment where S. altissimum were not removed from around ant colonies (Schmasow and Robertson 2016), S. altissimum seeds were detected frequently both in soil core samples and foraging observations of ants returning to their nests.

We found no significant differences between treatment and control colonies in the number of B. tectorum or P. secunda seeds present in surface soil cores taken one day prior to experimental manipulation (B. tectorum: Fig 1a, $\mathrm{t}=-1.32$, $\mathrm{df}=14, \mathrm{p}=0.209$; P. secunda: Fig $1 \mathrm{~b}, \mathrm{t}=1.30, \mathrm{df}=14, \mathrm{p}=0.215$ ). Between the start of the experiment and the first sampling date in July, the number of B. tectorum seeds in soil cores increased significantly both at treatment $(\mathrm{t}=6.54$, $\mathrm{df}=7, \mathrm{p}<0.0001)$ and control $(\mathrm{t}=5.04, \mathrm{df}=7, \mathrm{p}=0.002)$ colonies (Fig 1a), reflecting the release of new seeds. During this same period, $P$. secunda seed numbers increased significantly at control colonies $(t=2.086, d f=7, p=0.038)$, reflecting the release of new seeds, and dropped significantly at treatment colonies $(t=2.314, \mathrm{df}=7, \mathrm{p}=0.027)$, reflecting the consequences of trimming (Fig 1b). There was no significant difference in the abundance of B. tectorum seed between treatment and control colonies at either of the two sampling periods in July (Fig. 1a; $F_{1,14}=0.06, p=0.82$ ). By contrast, P. secunda seed was significantly less abundant around treatment colonies than around control colonies at both sampling dates in July $\left(\mathrm{F}_{1,14}=3.21, \mathrm{p}=0.047\right)$. The average difference in $\mathrm{P}$. secunda seed numbers between treatment and control colonies was $51.4 \%$ across the two sampling dates (Fig 1b). The interaction between treatment and sampling date in July for P. secunda was not statistically significant $\left(\mathrm{F}_{1,14}=2.87, \mathrm{p}=0.113\right)$.

\section{$\underline{\text { Seed Intake }}$}

Throughout the experiment, the only seeds we observed ants carrying to their nests were those of B. tectorum and $P$. secunda. We ignored the few instances in which ants were observed carrying items other than seeds (e.g., sticks and other vegetative debris, pebbles, arthropod carcasses). On average, ants belonging to treatment colonies gathered significantly more $B$. tectorum seeds than did ants from control colonies (Fig $2 ; F_{1,14}=8.18, p=0.013$ ). The increase in B. tectorum seed intake at treatment colonies was not mirrored by a decrease in $P$. secunda seeds returned to the nest (Fig $3 ; \mathrm{F}_{1,14}=0.0, \mathrm{p}=0.967$ ). Moreover, total seed intake (B. tectorum plus $P$. secunda) at colonies was not significantly 
This is an author-produced, peer-reviewed version of this article. The final, definitive version of this document can be found online at Journal of Insect Behavior, published by Springer. Copyright restrictions may apply. doi: 10.1007/s10905-018-9685-x

different between treatment and control $\left(\mathrm{F}_{1,14}=1.11, \mathrm{p}=0.310\right)$. Regardless of treatment, $B$. tectorum seeds represented only a small fraction of the total number of seeds returned by ants to their nests $(8.2 \pm 1.4 \%$ and $3.9 \pm 1.6 \%$ at treatment and control colonies, respectively).

\section{Trunk Trail Formation}

Treatment colonies were significantly more likely than control colonies to have at least one trunk trail that extended beyond $12 \mathrm{~m}$ of the nest (Table $1 ; \chi^{2} \mathrm{CMH}=8.21, \mathrm{df}=1, \mathrm{p}=0.004$ ). Ants returning along trunk trails from beyond $12 \mathrm{~m}$ of their nest were often observed carrying $P$. secunda seeds but never $B$. tectorum seeds; however, no quantitative assessment of food items being returned from beyond $12 \mathrm{~m}$ was made.

\section{Discussion}

Harvester ants in the genus Pogonomyrmex collect seeds from a wide range of plants, although they tend to specialize on abundant, small-seeded species (Crist and MacMahon 1992; MacMahon et al. 2000; Pirk et al. 2009; Pirk and Lopez de Casenave 2011; Ostoja et al. 2013; Schmasow and Robertson 2016). Diet selection is influenced by the nutrient requirements of the colony (Kay 2004), the morphological and nutritional characteristics of available seeds (Kelrick et al. 1986; Crist and MacMahon 1992; Pirk and Lopez de Casenave 2010; Hickey et al. 2016), and the temporal abundance and distribution of seeds in the environment (Whitford 1978; Briese and Macauley 1981; Crist and MacMahon 1992; Pirk et al. 2009; Pol et al. 2011). Our study shows that both diet selection and foraging range of Owyhee harvester ants are responsive to reductions in preferred seeds on the soil surface near nests. Ants increased their uptake of cheatgrass (Bromus tectorum) seeds, a less-preferred food type, from 3.9\% to $8.2 \%$ of diet when the number of Sandberg bluegrass (Poa secunda) seeds, a more-preferred food type, was reduced by more than $50 \%$ on the soil surface within $12 \mathrm{~m}$ of nests. Despite this modification in diet, collection of bluegrass seeds remained high and very similar between treatment and control colonies. Ants at treatment colonies may have augmented their intake of bluegrass seeds by traveling to more distant food patches - treatment colonies were significantly more likely than control colonies to have at least one trunk trail extending beyond the $12 \mathrm{~m}$ foraging range of the colony, and ants returning along these trails were observed carrying bluegrass seeds but not cheatgrass seeds. Thus, our results suggest that while the reduction in bluegrass seed availability resulted in a small increase in uptake of cheatgrass seeds, ants continued to exhibit a strong preference for bluegrass seeds by traveling farther for these seeds and by maintaining high levels of these seeds in their diet.

Foraging theory predicts that the inclusion of a specific prey type will depend not on its own encounter rate, but rather on the encounter rate of more profitable prey items (Stephens and Krebs 1986). Support for this prediction, while mixed, is found across a wide range of studies, particularly in those where prey items are immobile (e.g., seeds, nectar and leaves) (Sih and Christensen 2001). In the seed-harvesting ant Messor bouvieri, inclusion of less-preferred seeds in the diet (i.e., those from smaller-seeded species) is strongly dependent on the abundance of more-preferred seeds (i.e., those from larger-seeded species) (Willott et al. 2000). Likewise, in a study of Pogonomyrmex occidentalis, Crist and MacMahon (1992) found that increases in the abundance of cheatgrass seeds, the seeds least preferred by ants in their study, did not lower total seed intake rates for preferred species. In our study, Owyhee harvester ants increased their collection of cheatgrass seeds following experimental reduction of bluegrass seeds around nests, which suggests that the economics of including cheatgrass seeds in the diet became more favorable when bluegrass seeds became less locally abundant. Moreover, because bluegrass seeds present around treatment colonies (Fig 1b, open bars) were likely seeds left over from previous years, their nutritional quality may have been low compared to the freshly deposited seeds that contributed to the surface seed pool around control colonies. In a shrub-steppe ecosystem similar to ours, Crist and Friese (1993) found that fungal pathogens and decomposition reduced seed viability of Poa canbyi and several other species over time, and that Pogonomyrmex occidentalis foragers were more likely to avoid moldy seeds than control seeds. In our study, lower quality of leftover bluegrass seeds relative to freshly dropped seeds may have contributed to the increase in uptake of cheatgrass seeds around treatment colonies. However, further study is needed to determine whether Owyhee harvester ants discriminate between freshly dropped bluegrass seeds and those left over from previous years.

Surprisingly, the reduction in bluegrass seeds around treatment nests, and the concomitant uptick in the proportion of cheatgrass seeds in ant diet, was not mirrored by a detectable reduction in the number of bluegrass seeds returned to nests by ants, or by a change in total seed intake. These results may be an artifact of the relatively small change, 
This is an author-produced, peer-reviewed version of this article. The final, definitive version of this document can be found online at Journal of Insect Behavior, published by Springer. Copyright restrictions may apply. doi: 10.1007/s10905-018-9685-x

statistically significant though it was, found in cheatgrass seed intake at treatment colonies. Had the modification in diet been more dramatic in terms of cheatgrass seed intake, a detectable corresponding reduction in bluegrass seed intake, or an increase in total seed intake, would be expected.

In assessing the increase in cheatgrass seed intake at treatment colonies, we cannot rule out the possibility that the trimming of bluegrass may have created conditions on the ground that allowed ants to travel more efficiently with cheatgrass seeds, thereby leading to an increase in uptake of those seeds. For example, Hickey et al. (2016) found that reduced ground cover significantly increased the travel speed of seed-carrying Pogonomyrmex occidentalis, and the likelihood that Ephedra viridis seeds would be harvested by the ants. A major hindrance to ants transporting cheatgrass seeds is that the seed's awn repeatedly catches in vegetation, which forces ants to retrace their steps and find alternative pathways back to the nest, assuming individuals do not discard their seeds entirely (personal observations). Because vegetation at ground level adversely affects travel speed in Pogonomyrmex ants (Fewell 1988; Hickey et al. 2016), the creation of open spaces via trimming and raking might have facilitated travel of ants carrying cheatgrass seeds, thereby increasing the seed's profitability as food. However, this explanation seems unlikely given that the trimming procedure we used only affected the upper reaches of bluegrass, not the growth of plants at ground level, and raking was used to clear vegetative debris at both treatment nests (bluegrass and S. altissimum debris) and control nests (S. altissimum debris only).

In each of the four weeks in which we sampled ants as they returned to their nests with food, more treatment colonies than control colonies had at least one active trunk trail that extended beyond $12 \mathrm{~m}$ of the nest. Because trunk trails function as conduits to food patches (Hölldobler 1976; Gordon 1995; MacMahon et al. 2000), their increased presence around treatment nests may indicate that ants from those colonies were making forays beyond their normal foraging range to locate and exploit patches of bluegrass. In support of this argument, ants returning along trunk trails that extended beyond $12 \mathrm{~m}$ of their nest were often observed carrying bluegrass seeds, but never cheatgrass or other seeds. Although it is unclear the extent to which bluegrass seeds collected beyond $12 \mathrm{~m}$ of nests contributed to total seed intake, the extended forays made by ants to collect bluegrass seeds illustrate the strong preference ants have for these seeds compared to those of cheatgrass. In future studies, it would be interesting to explore the tradeoff between foraging distance and diet selection by examining how far ants will travel to locate and collect preferred seeds such as bluegrass when acceptable, but less-preferred seeds like those of cheatgrass remain abundant closer to the nest.

The influence of temporal changes in relative seed abundance on diet selectivity has been central to a number of studies aimed at understanding the foraging decisions of harvester ants (Briese and Macauley 1981; Melhop and Scott 1983; Wilby and Shachak 2000; Crist and MacMahon 1992; Pirk et al. 2009; Pol et al. 2011; Schmasow and Robertson 2016). For example, Pirk et al. (2009) found that three species of Pogonomyrmex exhibited a more generalist diet at the beginning of the season when preferred grass seeds were scarce. Likewise, Crist and MacMahon (1992) and Schmasow and Robertson (2016) found that seed preferences of harvester ants ( $P$. occidentalis and P. salinus, respectively) were correlated with the seasonal availability of preferred species, but not with less preferred species. In the present study, using a controlled experiment, we found that diet selection and foraging range in $P$. salinus are responsive to the abundance of preferred seeds distributed naturally on the soil surface around nests. Our approach involved manipulating seed availability throughout the foraging range of individual colonies, rather than by placing seeds within discrete patches near trunk trails as is generally the case in artificial food-patch studies. Because the foraging behavior of harvester ants can be influenced by proximity of seeds to trunk trails (Mull and MacMahon 1997), abundance and dispersion of seeds (Bernstein 1975; Pol et al. 2011; Flanagan et al. 2012), microhabitat cover (Hickey et al. 2016), and distance from colonies (Crist and MacMahon 1992; Mull and MacMahon 1997), artificial food-patch studies may overlook aspects of the natural foraging environment that are important to diet selection (Crist and MacMahon 1992; Pirk and Lopez de Casenave 2010). Manipulation of seed availability throughout the foraging range of individual colonies offers an alternative approach that may better reflect the natural environment experienced by foragers. It remains to be seen whether this approach can be effectively implemented in environments that present harvester ants with more complex food choice decisions. 
This is an author-produced, peer-reviewed version of this article. The final, definitive version of this document can be found online at Journal of Insect Behavior, published by Springer. Copyright restrictions may apply. doi: 10.1007/s10905-018-9685-x

\section{References}

Belchior C, Del-Claro K, Oliveira PS (2012) Seasonal patterns in the foraging ecology of the harvester ant Pogonomyrmex naegelii (Formicidae, Myrmicinae) in a Neotropical savanna: daily rhythms, shifts in granivory and carnivory, and home range. Arthropod-Plant Inte 6:571-582

Bernstein RA (1975) Foraging strategies of ants in response to variable food density. Ecology 56:213-219

Briese DT, Macauley BJ (1981) Food collection within an ant community in semi-arid Australia, with special reference to seed harvesters. Aust J Ecol 6:1-19

Cochran WG (1954) Some methods for strengthening the common $\chi^{2}$ tests. Biometrics 10:417-451

Crist TO, Friese CF (1993) The impact of fungi on soil seeds: implications for plants and granivores in a semiarid shrub-steppe. Ecology 74:2231-2239

Crist TO, MacMahon JA (1992) Harvester ant foraging and shrub-steppe seeds: interactions of seed resources and seed use. Ecology 73:1768-1779

Davidson DW (1978) Experimental tests of optimal diet in two social insects. Behav Ecol Sociobiol 4:35-41

Detrain C, Pasteels JM (2000) Seed preferences of the harvester ant Messor barbarus in a Mediterranean mosaic grassland (Hymenoptera: Formicidae). Sociobiology 35:35-48

Detrain C, Tasse O, Versaen M, Pasteels JM (2000) A field assessment of optimal forging in ants: trail patterns and seed retrieval by the European harvester ant Messor barbarus. Insect Soc 47:56-62

Fewell JH (1988) Variation in foraging patterns of the western harvester ant, Pogonomyrmex occidentalis, in relation to variation in habitat structure. In: Jeanne RL (ed) Interindividual Behavioral Variability in Social Insects. Westview Press, Colorado, pp 257-282

Fewell JH, Harrison JF (1991) Flexible seed selection by individual harvester ants, Pogonomyrmex occidentalis. Behav Ecol Sociobiol 28:377-384

Flanagan TP, Letendre K, Burnside WR, Fricke GM, Moses ME (2012) Quantifying the effect of colony size and food distribution on harvester ant foraging. PLoS ONE 7(7): e39427 doi: 10.1371/journal.pone.0039427

Gordon DM (1991) Behavioral flexibility and the foraging ecology of seed-eating ants. Am Nat 138:379-411

Gordon DM (1995) The development of an ant colony's foraging range. Anim Behav 49:649-659

Gross CL, Whalen MA, Andrew MH (1991) Seed selection and removal by ants in tropical savanna woodland in northern Australia. J Trop Ecol 7:99-112

Guarino R, Ferrario B, Mossa L (2005) A stochastic model of seed dispersal pattern to assess seed predation by ants in annual dry grasslands. Plant Ecol 178:225-235

Heredia A, Detrain C (2005) Influence of seed size and seed nature on recruitment in the polymorphic harvester ant Messor barbarus. Behav Process 70:289-300

Hickey A, Hollander J, Peacock M (2016) Assessing microhabitat cover and distance effects on harvester ant intraspecific seed preference. J Insect Behav 29:535-547

Holder Bailey K, Polis GA (1987) Optimal and central-place foraging theory applied to a desert harvester ant, Pogonomyrmex californicus. Oecologia 72:440-448

Hölldobler B (1976) Recruitment behavior, home range orientation and territoriality in harvester ants, Pogonomyrmex. Behav Ecol Sociobiol 1:1-44

Howell BD, Robertson IC (2015) Reclaiming lost territory: the response of Owyhee harvester ants to forager intrusions by neighboring colonies. J Insect Behav 28:722-731.

Johnson RA (2000) Seed-harvester ants (Hymenoptera: Formicidae) of North America: an overview of ecology and biogeography. Sociobiology 36:89-122

Kay A (2004) The relative availabilities of complementary resources affect the feeding preferences of ant colonies. Behav Ecol 15:63-70

Kelrick MI, MacMahon JA, Parmenter RR, Sisson DV (1986) Native seed preferences of shrub-steppe rodents, birds, and ants: the relationships of seed attributes and seed use. Oecologia 68:327-337

Kerley GIH, Landman M, de Beer S (2010) How do small browsers respond to resource changes? Dietary response of the Cape grysbock to clearing alien Acacias. Funct Ecol 24:670-675

MacArthur RH, Pianka ER (1966) On optimal use of a patchy environment. Am Nat 100:603-609

MacMahon JA, Mull JF, Crist TO (2000) Harvester ants (Pogonomyrmex spp.): their community and ecosystem influences. Ann Rev Ecol Syst 31:265-291

Mantel N, Haenszel W (1959) Statistical aspects of the analysis of data from retrospective studies of disease. J Natl Cancer I 22:719-748

Mehlhop P, Scott (Jr.) NJ (1983) Temporal patterns of seed use availability in a guild of desert ants. Ecol Entomol 8:69-85. 
This is an author-produced, peer-reviewed version of this article. The final, definitive version of this document can be found online at Journal of Insect Behavior, published by Springer. Copyright restrictions may apply. doi: 10.1007/s10905-018-9685-x

Morehead SA, Feener DH Jr. (1998) Foraging behavior and morphology: seed selection in the harvester ant genus, Pogonomyrmex. Oecologia 114:548-555

Mull JF, MacMahon JA (1997) Spatial variation in rates of seed removal by harvester ants (Pogonomyrmex occidentalis) in a shrub-steppe ecosystem. Am Midl Nat 138:1-13

Ostoja SM, Schupp EW, Klinger R (2013) Seed harvesting by a generalist consumer is context dependent: Interactive effects across multiple spatial scales. Oikos 122:563-574

Peters M, Oberrath R, Böhning-Gaese K (2003) Seed dispersal by ants: are seed preferences influenced by foraging strategies or historical constraints? Flora 198:413-420

Piemeisel RL (1951) Causes affecting change and rate of change in a vegetation of annuals in Idaho. Ecology 32: 53-72

Pirk GI, Lopez de Casenave J, Pol RG, Marone L, Milesi FA (2009) Influence of temporal fluctuations in seed abundance on the diet of harvester ants (Pogonomyrmex spp.) in the central Monte desert, Argentina. Austral Ecol 34:908-919

Pirk GI, Lopez de Casenave J (2010) Influence of seed size on feeding preferences and diet composition of three sympatric harvester ants in the central Monte Desert, Argentina. Ecol Res 25:439-445

Pirk GI, Lopez de Casenave J (2011) Seed preferences of three harvester ants of the genus Pogonomyrmex (Hymenoptera: Formicidae) in the Monte desert: are they reflected in the diet? Ann Entomol Soc Am 104:212-220

Pol RG, Lopez de Casenave J, Pirk GI (2011) Influence of temporal fluctuations in seed abundance on the foraging behavior of harvester ants (Pogonomyrmex spp.) in the central Monte desert, Argentina. Austral Ecol 36:320-328

Schmasow MS, Robertson IC (2016) Selective foraging by Pogonomyrmex salinus (Hymenoptera: Formicidae) in semiarid grassland: implications for a rare plant. Environ Entomol 45: 952-960. doi10.1093/ee/nvw071

Sih A, Christensen B (2001) Optimal diet theory: when does it work, and when and why does it fail? Anim Behav 61:379-390

Stephens DW, Krebs JR (1986) Foraging Theory. Princeton University Press, New Jersey

Stephens DW, Brown JS, Ydenberg RC (2007) Foraging: Behavior and Ecology. University of Chicago Press, Chicago

Taber SW (1998) The World of the Harvester Ants. Texas A\&M University Press, College Station, TX.

Weier JA, Feener DH Jr (1995) Foraging in the seed-harvesting ant genus Pogonomyrmex: are energy constraints important? Behav Ecol Sociobiol 36:291-300

Whitford WG (1978) Foraging in seed-harvester ants Pogonomyrmex spp. Ecology 59:185-189

Wilby A, Shachak M (2000) Harvester ant response to spatial and temporal heterogeneity in seed availability: pattern in the process of granivory. Oecologia 125:495-503

Willott SJ, Compton SG, Incoll LD (2000) Foraging, food selection and worker size in the seed harvesting ant Messor bouvieri. Oecologia 125:35-44

Table 1. Weekly assessment of the number of treatment and control colonies that had one or more trunk trails extending beyond $12 \mathrm{~m}$ of the nest.

\begin{tabular}{lll}
\hline $\begin{array}{l}\text { Observation Period } \\
\text { (Week) }\end{array}$ & \multicolumn{2}{l}{$\begin{array}{l}\text { Number of colonies with one or more trunk trails } \\
\text { that extended beyond } 12 \text { m of nest }\end{array}$} \\
\cline { 2 - 3 } & Treatment $(\mathrm{N}=8)$ & Control $(\mathrm{N}=8)$ \\
\hline 1 & 4 & 1 \\
2 & 4 & 1 \\
3 & 5 & 2 \\
4 & 3 & 1 \\
\hline
\end{tabular}

\section{Figure Captions}

Figure 1. Availability of (a) cheatgrass and (b) Sandberg bluegrass seeds on the soil surface at treatment (open bars, $\mathrm{N}=8$ ) and control (filled bars, $\mathrm{N}=8$ ) colonies. Sampling dates are shown as Month (week). The May sampling date represents conditions at the start of the experiment, prior to the trimming of bluegrass at treatment colonies. The July 
This is an author-produced, peer-reviewed version of this article. The final, definitive version of this document can be found online at Journal of Insect Behavior, published by Springer. Copyright restrictions may apply. doi: 10.1007/s10905-018-9685-x

sampling dates show seed numbers six and eight weeks after bluegrass fruiting structures had been trimmed around treatment colonies. Seed numbers (mean $\pm \mathrm{SE}$ ) are scaled to the $12 \mathrm{~m}$ foraging radius around colonies. Different letters above bars indicate significant differences (see text for details).

Figure 2. Mean number of cheatgrass seeds $( \pm \mathrm{SE})$ returned to nests during each 5-minute observation period at treatment (open bars, $\mathrm{N}=8$ ) and control (filled bars, $\mathrm{N}=8$ ) colonies $(\mathrm{F} 1,14=8.18, \mathrm{p}=0.013)$. Sampling dates are shown as Month (week).

Figure 3. Mean number of Sandberg bluegrass seeds $( \pm \mathrm{SE})$ returned to nests during each 5-minute observation period at treatment (open bars, $\mathrm{N}=8)$ and control (filled bars, $\mathrm{N}=8$ ) colonies $\left(\mathrm{F}_{1,14}=0.0, \mathrm{p}=0.967\right)$. Sampling dates are shown as Month (week). 


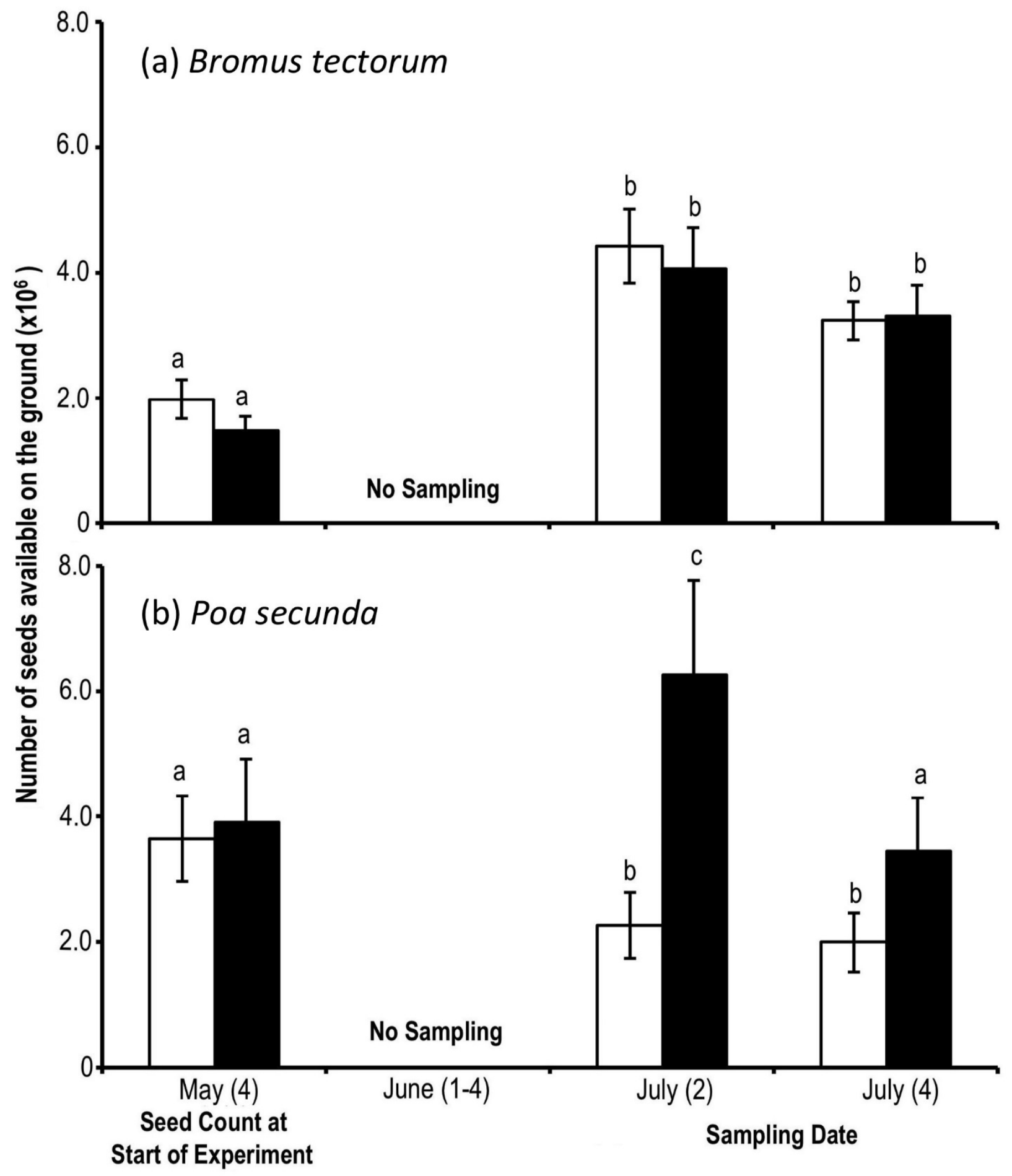

Fig 1 - Robertson \& Schmasow 


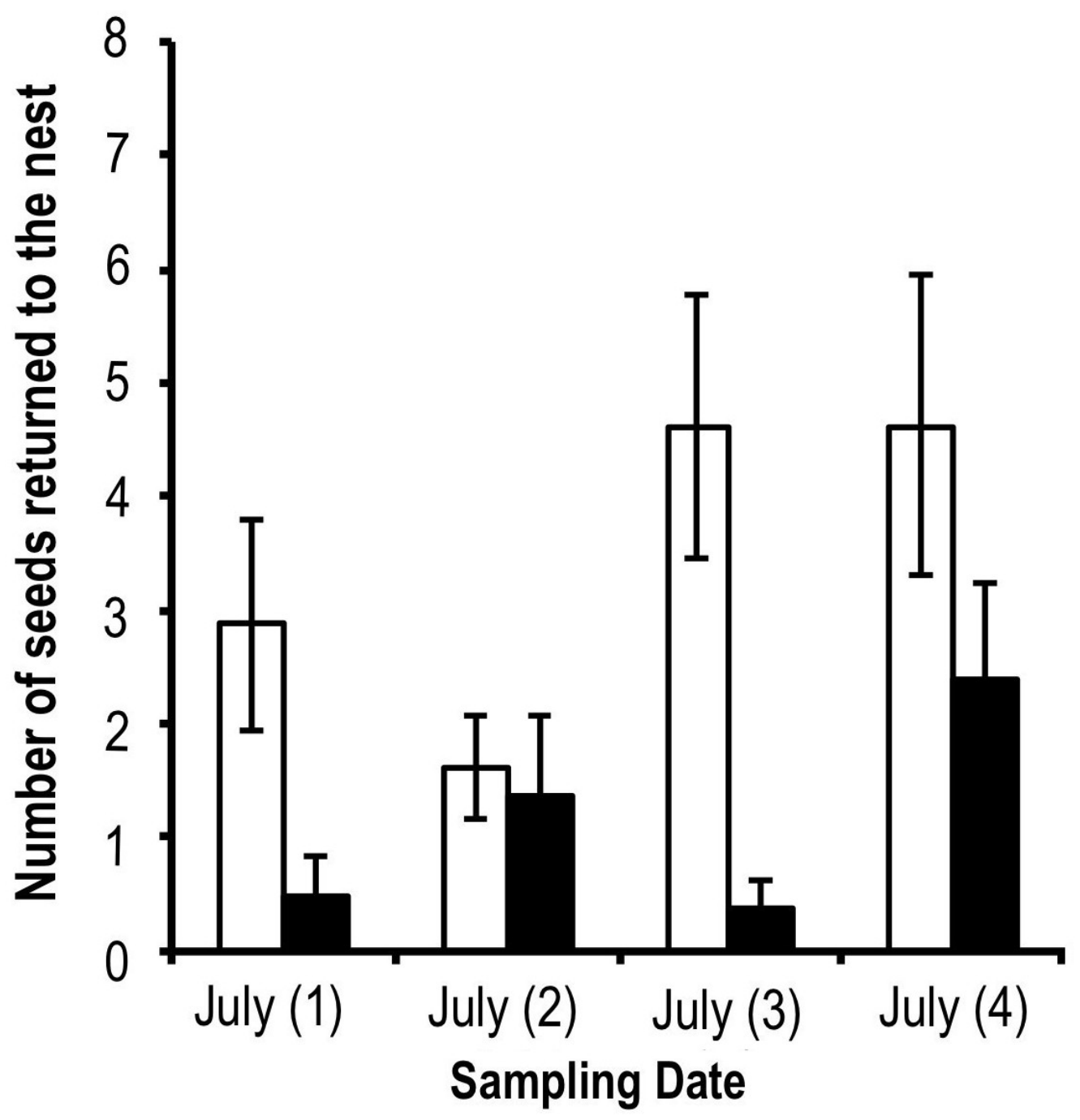

Fig 2 - Robertson \& Schmasow 


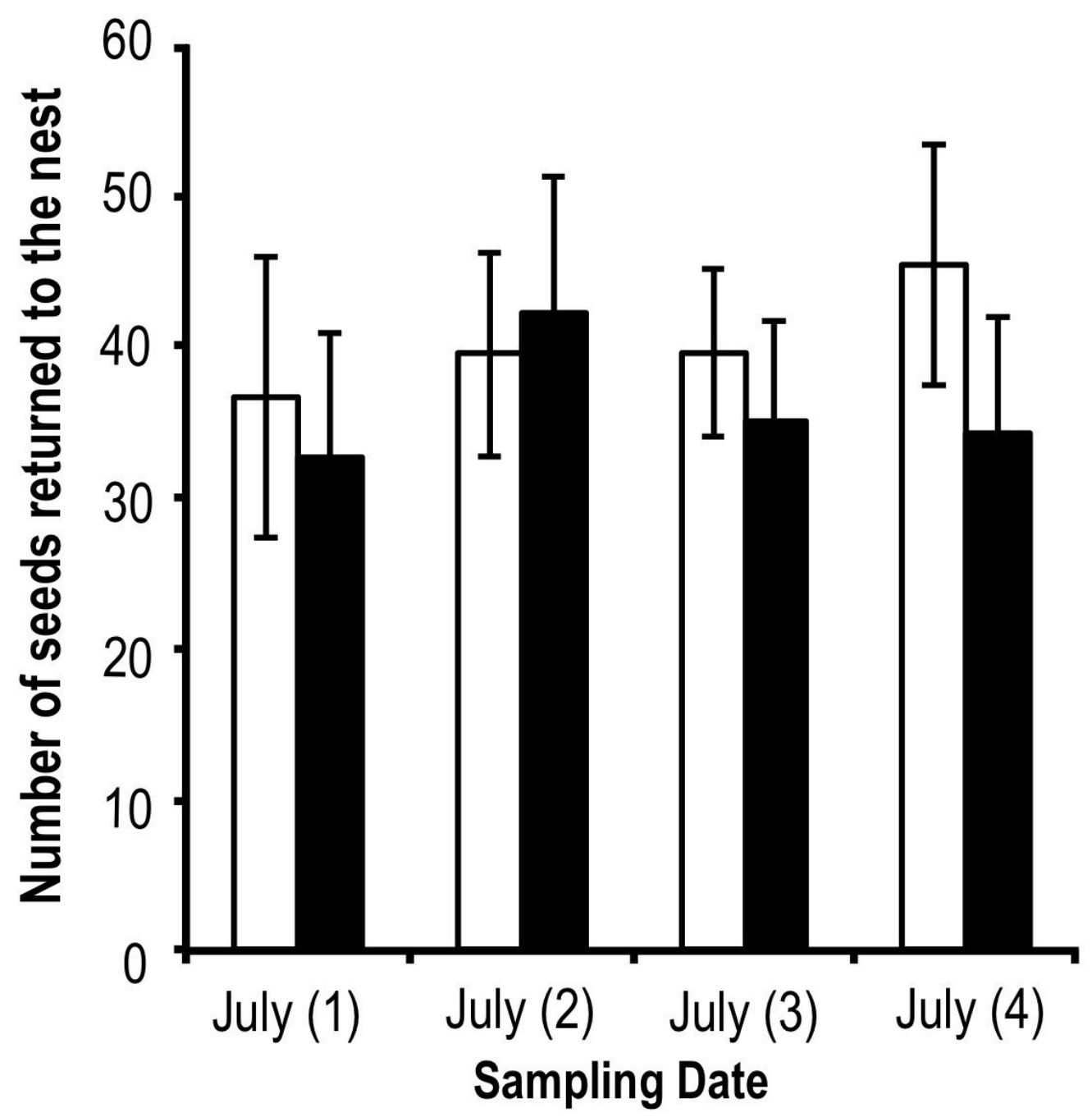

Fig 3 - Robertson \& Schmasow 